\title{
Protective effects of the cumulus-corona radiata complex during vitrification of horse oocytes
}

\author{
T Tharasanit ${ }^{1}$, S Colleoni ${ }^{2}$, C Galli ${ }^{2,3}$, B Colenbrander $^{1}$ and T A E Stout ${ }^{1,4}$ \\ ${ }^{1}$ Department of Equine Sciences, Faculty of Veterinary Medicine, Utrecht University, Yalelaan 112, 3584 CM Utrecht, \\ The Netherlands, ${ }^{2}$ Laboratorio di Tecnologie della Riproduzione, Instituto Sperimentale Italiano Lazzaro Spallanzani, \\ Via Porcellasco 7/F, Cremona 26100, Italy, ${ }^{3}$ Faculty of Veterinary Medicine, University of Bologna, V. Tolara di Sopra \\ 50, Ozzano Emilia, Bologna, Italy and ${ }^{4}$ Department of Production Animal Sciences, University of Pretoria, Pretoria \\ 0002, South Africa
}

Correspondence should be addressed to T A E Stout; Email: t.a.e.stout@uu.nl

\begin{abstract}
Vitrifying oocytes is a potentially valuable means of preserving the female germ line, but significantly compromises oocyte developmental competence. This study examined the hypothesis that the cumulus complex protects the oocyte during vitrification. Vitrified-warmed immature cumulus oocyte complexes (COCs) were labelled with a plasma membrane impermeant DNA marker (ethidium homodimer-1) to examine the percentage and location of dead cumulus cells, and to investigate the effect of the proportion of dead cells $(+1,+2$ or +3$)$ on the success of in vitro maturation (IVM). Further, oocytes were labelled for connexin-43 or injected with Lucifer yellow dye to determine whether the integrity of the gap junctions between an oocyte and its cumulus was compromised by vitrification. Finally, the effect of denuding immature and mature oocytes on their ability to withstand vitrification was examined. Cryopreserving immature COCs increased the number of dead cumulus cells (13 vs $2.6 \%$ for controls; $P<0.05)$. However, an increased proportion of dead cumulus cells did not affect post-warming maturation rates $(\sim 30 \% \mathrm{MII})$ presumably because dead cells were located at the periphery of the cumulus mass and cumulus-oocyte gap junction communication was not disrupted. Moreover, cumulus removal prior to IVM or vitrification indicated that while the cumulus does protect immature oocytes during vitrification it does so by mechanisms other than support during maturation. Cumulus presence was also found to protect mature equine oocytes against vitrification-induced damage since cumulus-enclosed MII oocytes preserved their meiotic spindle quality better during vitrification than denuded oocytes (38.1 vs $3.1 \%$ normal spindles; $P<0.05$ ).

Reproduction (2009) 137 391-401
\end{abstract}

\section{Introduction}

Oocyte cryopreservation is a potentially valuable means of preserving the female germ line from genetically valuable domestic or wild animals, and for preserving fertility potential in women requiring chemo- or radiotherapy or wishing to delay childbirth until late in their reproductive life. Cryopreserved oocytes can, in theory, be used to produce offspring via assisted reproductive techniques such as in vitro embryo production (Fuku et al. 1992, Vajta et al. 1998) or oocyte transfer (Maclellan et al. 2002), and can also serve as host cytoplasts for cloning by nuclear transfer (Kubota et al. 1998, Dinnyes et al. 2000, Atabay et al. 2004). However, while offspring have been produced using frozen-thawed oocytes in various species (e.g. human: Chen 1986, Chian et al. 2009; cow: Fuku et al. 1992; horse: Maclellan et al. 2002), the overall success of oocyte cryopreservation in terms of the subsequent ability to support embryo development is low. In this respect, oocytes are susceptible to damage during cooling and/or freezing and thawing (Leibo 1980) because they are structurally complex and relatively impermeable to both water and cryoprotectants (CPAs; Agca et al. 1998). While the specific molecular elements or pathways disrupted during oocyte cryopreservation are not well characterised, many ultrastructural elements critical to the maintenance of developmental competence are damaged during freezing and thawing (Parks \& Ruffing 1992), including the plasma membrane (Ashwood-Smith et al. 1988), the actin cytoskeleton and the meiotic spindle (Sathananthan et al. 1988, Park et al. 1997). Oocyte cryopreservation can also lead to 'zona hardening', as a result of CPA-induced premature cortical granule release (Ghetler et al. 2006), and it is for this reason that cryopreserved human oocytes are usually fertilised by intracytoplasmic sperm injection rather than by conventional IVF (for reviews see Coticchio et al. 2007, Gook \& Edgar 2007).

In the horse, it is clear that immature (germinal vesicle stage: GV) oocytes suffer considerable damage during controlled-rate freezing because $<16 \%$ reach 
metaphase of the second meiotic division (MII) during post-thaw in vitro maturation (IVM; Hochi et al. 1994, Tharasanit et al. 2006a); this compares unfavourably to the $50-80 \%$ MII rates typical for non-cryopreserved oocytes (Hinrichs 1998). While the meiotic competence of GV horse oocytes conserved by vitrification is much better (28-46\% MII rate: Hurtt et al. 2000, Tharasanit et al. 2006a, 2006b), even then $\sim 50 \%$ of the oocytes that reach MII exhibit abnormalities of the meiotic spindle, and developmental competence is poor (Tharasanit et al. 2006a, 2006b).

Although the extent and exact causes of reduced developmental competence following cryopreservation may vary between species, factors shown to contribute to reduced oocyte quality include damage to the mitochondria in equine oocytes (Hochi et al. 1996) and enzymes critical to oocyte maturation and subsequent embryo development in sheep (e.g. MAP kinase, MPF: Bogliolo et al. 2007). It has also been proposed that damage to the cumulus investment plays a role in compromised developmental competence since freezing and thawing damages cumulus cells surrounding mouse oocytes (Ruppert-Lingham et al. 2003) and the gap junctions between equine oocytes and their surrounding cumulus-corona radiata cells (Hochi et al. 1996), where the interaction between oocyte and cumulus has been shown to be critical to successful nuclear and cytoplasmic maturation for at least bovine oocytes (Zhang et al. 1995, Hassan 2001, Tanghe et al. 2003). While Bogliolo et al. (2007) reported a counterintuitive improvement in survival and meiotic competence for immature sheep oocytes denuded of their cumulus prior to vitrification, they also noted the depletion of enzymes (MPF and MAPK) required to support embryo development.

In theory, when oocytes are cryopreserved at the MII stage removal of, or damage to, the cumulus investment should have fewer detrimental consequences because the cumulus plays little role in subsequent development. However, cumulus cell secretions and gap junctional contact between the oocyte and corona radiata cells have been reported to promote sperm penetration and thereby improve fertilisation rates in conventional IVF systems for both cattle (Tanghe et al. 2003) and cats (Godard et al. 2009). More controversially, Imoedemhe \& Sigue (1992) reported that the cumulus investment protected MII oocytes against structural damage during cryopreservation. A similar protective effect of the cumulus during the vitrification of MII equine oocytes is inferred by the observations that horse oocytes vitrified at the MII stage within their cumulus investments were able to yield viable pregnancies (Maclellan et al. 2002), whereas vitrification of denuded MII horse oocytes led to a high incidence of spindle abnormalities (>65\%) and very poor developmental competence following intracytoplasmic sperm injection (Tharasanit et al. $2006 b$ ). On the other hand, current protocols for cryopreserving MII human oocytes almost universally involve prior denudation, since more recent studies have concluded that totally removing the cumulus prior to controlled-rate freezing does not reduce the viability of human oocytes (Fabbri et al. 2001), and may even improve the developmental competence of bovine oocytes vitrified using the cryotop technique (Chian et al. 2004).

The aims of the current study were to investigate the effect of open pulled straw (OPS) vitrification on the integrity of immature (GV) equine cumulus-oocyte complexes (COCs) in terms of cumulus cell viability, gap junction communication between oocyte and cumulus cells and the ability of the oocyte to complete nuclear maturation. In addition, we wished to determine whether removing the cumulus cells prior to vitrification affected meiotic competence or meiotic spindle quality in oocytes vitrified at the GV or MII stages.

\section{Results \\ Experiment 1: Effect of vitrifying immature COCs on cumulus cell viability}

Vitrifying immature COCs did not affect the gross morphology of the cumulus complex (Fig. 1A) but was associated with an increase in the proportion of dead cumulus cells ( 13.7 vs $2.6 \%$ for controls; Table $1 ; P<0.05$ ). It was, however, not possible to definitively ascribe the increased proportion of dead cells to an effect of vitrification because it transpired that vitrified-warmed COCs also had higher total cumulus cell numbers than either control group. Nevertheless, any effect of vitrification was not due simply to CPA toxicity because exposure of COCs to CPA without subsequent vitrification did not affect cumulus cell viability ( $2.7 \%$ dead cells).

Confocal laser-scanning microscope (CLSM; Leica TSC MP, Heidelberg, Germany) analysis revealed that in nearly all vitrified-warmed COCs, the vast majority of dead cumulus cells (i.e. ethidium homodimer-1 (Ethd-1) positive cells) were located at the periphery of the cumulus mass, while no dead cells were observed within the innermost 2-3 layers of cumulus/corona radiata cells surrounding the oocyte (Fig. 1B and C). In addition, the actin cytoskeleton of live cumulus cells within vitrifiedwarmed immature COCs was well organised with intense staining beneath the cell plasma membrane (Fig. 1D), exactly as in control non-frozen COCs, indicating that actin cytoskeleton damage in the cumulus cells that survived vitrificiation was minimal or reparable.

\section{Experiment 2: Relationship between cumulus viability and meiotic competence of vitrified COCs}

When vitrified-warmed immature COCs were divided into cumulus quality classes on the basis 
of the proportion of dead cells estimated by Ethd-1 staining, there was no discernable effect of postwarming cumulus quality $(+1,+2$ or +3 dead cells) on the maturation rate during subsequent IVM (Table 2). However, the percentage of oocytes that successfully progressed to MII was significantly lower in vitrified-warmed oocytes of all cumulus quality groups than in non-cryopreserved controls ( 30 vs $60 \%$ : $P<0.05)$.
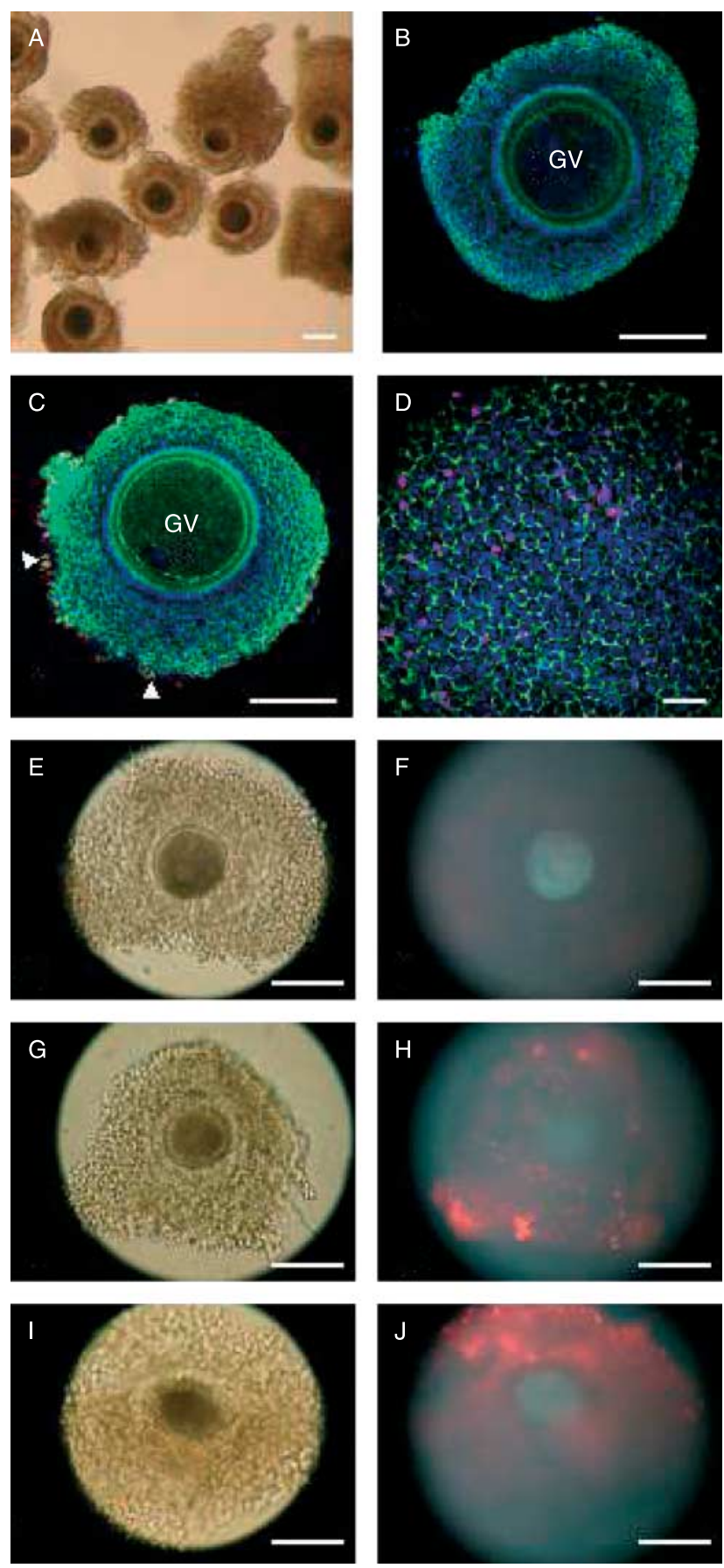

\section{Experiment 3: Effect of vitrification on COC connexin- 43 expression and gap junction function}

The gap-junction specific protein connexin-43 was present in both control and vitrified COCs and was localised to the cell plasma membrane between neighbouring cumulus (Fig. 2A) or corona radiata cells (Fig. 2B). There was no apparent difference in the pattern of connexin-43 expression between control and vitrified COCs.

Following Lucifer yellow (LY) injection and a $10 \mathrm{~min}$ post-injection incubation, $\sim 50$ and $28 \%$ of vitrifiedwarmed oocytes had fully 'open' or completely 'closed' gap junctions respectively (Table 3; Fig. 2C-E). This was very similar to the pattern of gap junction function in non-treated or CPA-exposed control COCs.

\section{Experiment 4: Effect of cumulus removal on meiotic competence and cryopreservability of GV oocytes}

Denuding GV horse oocytes of their cumulus complex had no significant effect on their ability to reach MII during IVM or on the percentage that displayed a normal MII spindle after maturation (Table 4). By contrast, when denudation was followed by CPA exposure, a higher percentage of oocytes showed evidence of spindle disruption (60 vs 11\%: Table 4) even though the percentage that reached MII was similar to the control group (50 vs 55\%). When GV oocytes were vitrified in the absence of the cumulus, both the percentage reaching MII (22\%) and the percentage of MII oocytes with a normal looking spindle $(18 \%)$ were reduced considerably as compared with controls (Table 4).

\section{Experiment 5: Effect of cumulus cell removal on the ability of in vitro matured oocytes to withstand vitrification}

Vitrification of MII oocytes led to meiotic spindle damage and chromosome dispersal. Indeed, despite a

Figure 1 Photomicrographs to demonstrate the effects of vitrification on the viability of cumulus cells within equine COCs. Scale bars represent $100 \mu \mathrm{m}(\mathrm{A}-\mathrm{C}, \mathrm{E}-\mathrm{J})$ and $50 \mu \mathrm{m}$ (D). (A) COCs exhibited normal gross morphology after vitrification and warming. (B-D) Confocal laserscanning micrographs of immature (germinal vesicle stage; GV) COCs. The COCs have been stained with ethidium homodimer-1 (red), Alexa Fluor 488 phalloidin (green) and $\mathrm{TOPRO}_{3}$ (blue) to identify dead cells, actin microfilaments and live cells respectively. (B) is a non-frozen control COC within which no dead cumulus cells can be seen. (C and D) are vitrified-warmed COCs that illustrate the localisation of dead cells (arrow heads) to the periphery of the cumulus mass (C), and the maintenance of good actin cytoskeleton quality in surviving cumulus cells typified by precise restriction of actin microfilament staining to the cell cortex (D). (E-J) Bright field (E, G, I) and fluorescent $(F, H, J)$ photomicrographs of the same vitrified-warmed COCs to demonstrate how COCs were classified according to the proportion of dead (Ethd-1 positive) cumulus cells. $(\mathrm{F}),(\mathrm{H})$ and $(\mathrm{J})$ are examples of $+1,+2$ and +3 grade COCs respectively. 
Table 1 Proportion of cumulus cells that were dead after vitrification or cryoprotectant (CPA) exposure of immature equine cumulus oocyte complexes (COCs).

\begin{tabular}{lccc}
\hline Group & Number of COCs & \% Dead cells (mean \pm s.E.M.) & $\begin{array}{c}\text { Total cumulus cells per COC } \\
\text { (mean } \pm \text { s.E.M.) }\end{array}$ \\
\hline Vitrified-warmed & 48 & $13.7 \pm 1.0^{\mathrm{b}}$ & $521 \pm 24.9^{\mathrm{b}}$ \\
CPA-exposed/not vitrified & 26 & $2.7 \pm 0.3^{\mathrm{a}}$ & $438 \pm 28.3^{\mathrm{a}}$ \\
Untreated controls & 26 & $2.6 \pm 0.3^{\mathrm{a}}$ & $471 \pm 27.2^{\mathrm{a}}$ \\
\hline
\end{tabular}

a,b Within a column, different superscripts denote values that differ significantly $(P<0.05)$.

$6 \mathrm{~h}$ post-warming incubation to allow spontaneous spindle repair, only respectively 21 and $24 \%$ of all vitrified oocytes were classified as having a normal meiotic spindle and minimal chromatin dispersal after warming, compared with $94 \%$ of control oocytes (Table 5). Moreover, removal of the cumulus investment prior to vitrification was clearly detrimental to meiotic spindle quality, since only $3.1 \%$ of cumulus-denuded oocytes had a normal meiotic spindle after warming, compared with $38 \%$ of cumulus-intact COCs. Disruption of the meiotic spindle appeared to be primarily an effect of vitrification and warming per se, since exposure of oocytes to the vitrification solutions without freezing did not reduce meiotic spindle quality in either cumulus intact or denuded oocytes (Table 5).

\section{Discussion}

Vitrification markedly reduced the ability of immature equine oocytes to resume meiosis and progress to MII. Vitrification was also associated with the death of a modest proportion of cumulus cells, and although the results do not strictly allow us to differentiate between vitrification and initial cumulus cell number as the cause of the higher percentage of dead cells, the former is more likely since there was no correlation between cumulus cell number and proportion of dead cells in control COCs. Cryopreservation has previously been reported to lead to extensive cumulus cell damage (Ruppert-Lingham et al. 2003, Bogliolo et al. 2007), which in turn was associated with reductions in oocyte normality, meiotic competence and/or developmental capacity. However, while the proportion of dead

Table 2 Effect of the proportion of dead cumulus cells, as estimated using Ethd-1 staining, on the ability of vitrified-warmed equine oocytes to complete maturation in vitro (reach metaphase II).

\begin{tabular}{lcl}
\hline Group & Number of COCs & Metaphase II (\%) \\
\hline Untreated controls & 80 & $48(60)^{\mathrm{a}}$ \\
Ethd-1 exposed controls & 60 & $40(66.7)^{\mathrm{a}}$ \\
Vitrified +1 dead cells & 43 & $14(32.6)^{\mathrm{b}}$ \\
Vitrified +2 dead cells & 29 & $8(27.6)^{\mathrm{b}}$ \\
Vitrified +3 dead cells & 36 & $13(36.1)^{\mathrm{b}}$ \\
\hline
\end{tabular}

${ }^{a, b}$ Within a column, different superscripts denote values that differ significantly.

${ }^{*}$ COCs were classified into the categories $+1,+2$ and +3 depending on the proportion of cumulus cells that stained positive for Ethd- 1 (i.e. that were dead). cumulus cells increased after vitrification and warming in the current study, the dead cells were invariably located at the periphery of the cumulus cell mass, and there was no correlation between the proportion of dead cumulus cells $(+1,+2$ or +3$)$ and the ability of a COC to complete meiosis. It therefore appears that in immature equine COCs peripheral cumulus cells are more susceptible to 'cryoinjury' than those deeper in the cumulus mass, and that death of these peripheral cumulus cells does not greatly affect the ability of the oocyte to complete nuclear maturation.

While it is not clear exactly how cumulus cells support oocyte maturation, it is generally accepted that cumulus-oocyte communication via an intact corona radiata (Ge et al. 2008) is necessary for immature oocytes to resume meiosis and attain full cytoplasmic maturation and developmental competence (Vanderhyden \& Armstrong 1989, Tanghe et al. 2003), and that gap junctions play an important role in this communication (Shimada et al. 2001). Gap junctions are channels between adjoining cells that allow the passage of molecules less than $1 \mathrm{kDa}$ in size, such as ions, nutrients and metabolites (Gilula et al. 1972). Gap junctions appear to be critical to the transport of cumulus-derived factors that initiate oocyte maturation and GV breakdown (Mattioli \& Barboni 2000, Tanghe et al. 2002). In the current study, we chose immunolabelling for connexin-43 to demonstrate that gap junctions are present between cumulus and corona radiata cells because Marchal et al. (2003) had previously demonstrated that immature equine COCs contain connexin-43 but not connexin-32, another gap junction protein found in immature bovine COCs (Sutovsky et al. 1993). In fact, we found no difference in the approximate amount and distribution of connexin43 between vitrified and untreated COCs. There was also no apparent difference in gap junction function, as measured by the diffusion of LY, between vitrifiedwarmed and control immature COCs, thereby supporting the earlier conclusion that the detrimental effects of vitrificiation on the meiotic competence of GV horse oocytes are not due to disruption of cumulus function. This finding of minimal gap junction disruption differs from that of a previous study that used transmission electron microscopy to demonstrate damage to the gap junctions between the cumulus cells and oocyte in vitrified immature equine COCs (Hochi et al. 1996) and 
to the finding of a more recent study in which the vitrification markedly reduced the percentage of immature ovine COCs with open gap junctions (from 82 to 20\%: Bogliolo et al. 2007). However, Hochi et al. vitrified COCs in standard $0.25 \mathrm{ml}$ straws, and it is possible that the use of the thinner OPS straws in the current study contributed to a reduction in gap junction disruption. Indeed, the thin-walls of OPS straws and the small volume of vitrification medium that they contain have been prosposed to dramatically reduce the risk of cryo-injury and, thereby, improve post-thaw maturation rates in both bovine (Vajta et al. 1998, Hyttel et al. 2000) and equine (Hurtt et al. 2000) oocytes. Bogliolo et al.'s (2007) report of a dramatic fall in cumulus-oocyte communication in vitrified sheep oocytes was presumably related to the very much higher rates of cumulus
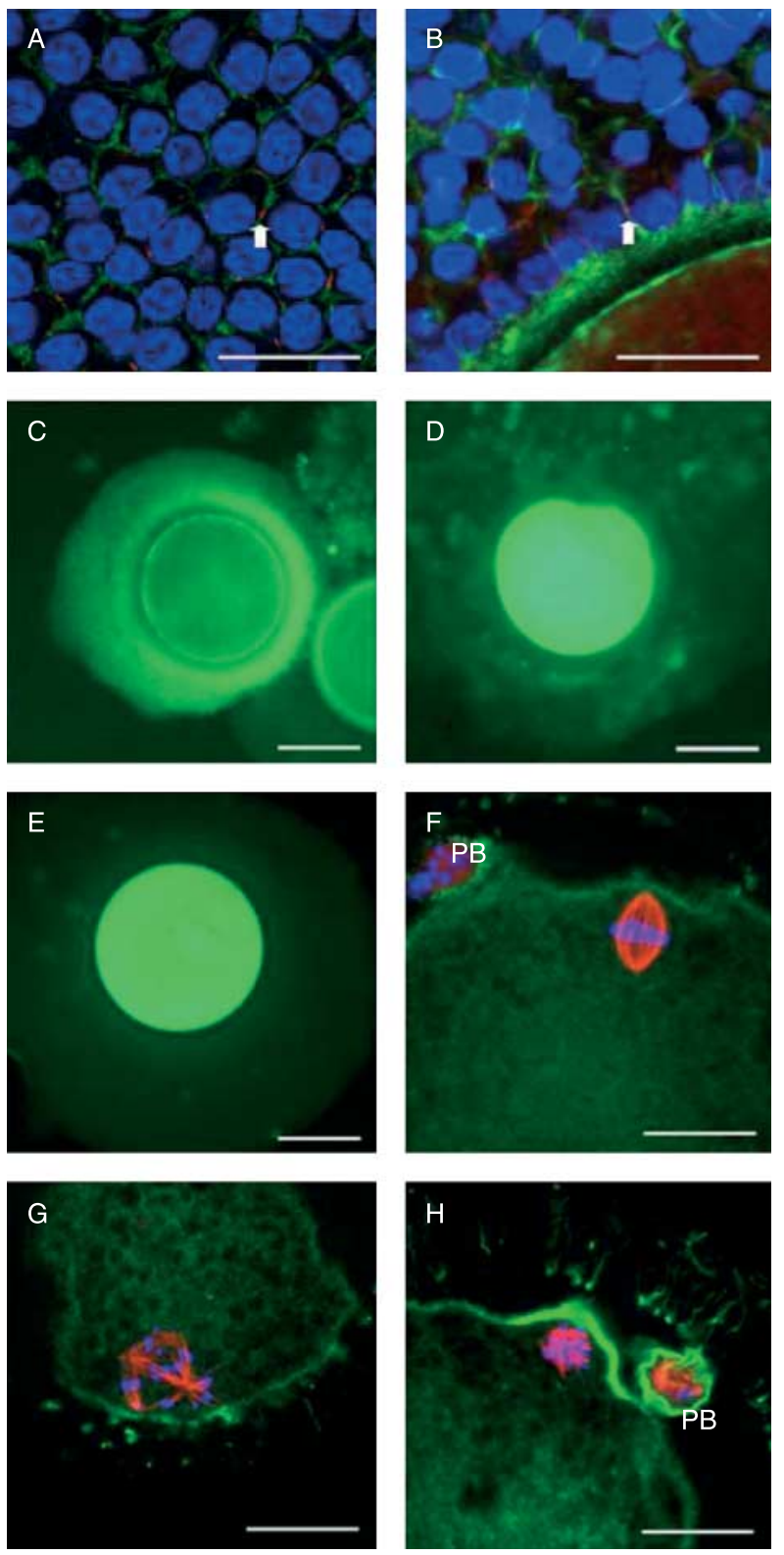

cell death that they observed, with more than $75 \%$ of the cumulus cells over the oocyte surface reported to be dead after warming in $64 \%$ of the vitrified oocytes.

As a result of the experiments that examined postwarming maturation, it was clear that meiotic competence of vitrified GV oocytes is appreciably lower than that of the control or CPA-exposed oocytes, irrespective of the proportion of dead cumulus cells. It therefore appears that vitrification reduces oocyte meiotic competence primarily by mechanisms other than cumulus cell death, e.g. by disrupting cytoplasmic proteins critical to the resumption of meiosis and progression from MI to MII, such as those involved in the MAP kinase cascade (Verlhac et al. 1994, Lu et al. 2002, Fan \& Sun 2004). More surprising was the finding that removing the cumulus complex resulted in reduced meiotic competence and MII spindle quality, only if the oocytes were subsequently vitrified or exposed to CPAs. It therefore appears that while the cumulus protects against both freezing-induced damage and CPA toxicity, it does so in a manner not related to any role in supporting nuclear maturation. Bogliolo et al. (2007) also recently concluded that cumulus cells are not essential to the preservation of meiotic competence during vitrification; however, they did so after finding that immature ovine oocytes survived cryopreservation better if they had previously been denuded. This discrepancy between an apparently protective effect of cumulus cells in our study and a detrimental effect in Bogliolo et al. (2007)'s study could relate either to a damaging effect of the large number of dead cumulus cells surrounding Bogliolo et al.'s vitrified-warmed oocytes or to a non-specific effect of cumulus enclosure in modifying the optimal time of exposure to the cryprotectants, as postulated for MII porcine oocytes by Fujihira et al. (2005). That is, in

Figure 2 Photomicrographs to demonstrate the expression of the gap junction protein, connexin-43 (A and B), the Lucifer yellow microinjection technique for analysing gap junction function $(\mathrm{C}-\mathrm{E})$, and normal and abnormal meiotic spindle and chromatin configurations in vitrified-warmed equine oocytes $(\mathrm{F}-\mathrm{H})$. Scale bars represent $12.5 \mu \mathrm{m}(\mathrm{A}$ and $\mathrm{B}), 50 \mu \mathrm{m}(\mathrm{C}, \mathrm{D}$ and $\mathrm{E})$ and $25 \mu \mathrm{m}(\mathrm{F}, \mathrm{G}$ and $\mathrm{H})$. (A and B) Localisation of the gap junction protein, connexin-43 (red), actin microfilaments (green) and nuclei (blue) in vitrified-warmed COCs. Connexin-43 (indicated by the arrows) was localised to the plasma membrane between neighbouring cumulus (A) or corona radiata (B) cells. (C-E) Classification of oocyte-cumulus gap junction function by the extent of Lucifer yellow diffusion into the cumulus complex $10 \mathrm{~min}$ after microinjection of the dye into the oocyte; (C) fully open, (D) partially open and (E) closed gap junctions. $(\mathrm{F}-\mathrm{H})$

Multiphoton micrographs illustrating cytoskeleton morphology in vitrified-warmed oocytes. Microtubules are stained in red, actin microfilaments in green and chromatin blue. (F) shows a normal symmetrical metaphase II spindle with two anastral poles and two equal sets of chromosomes aligned at its centre. (G) shows an oocyte with a severely disrupted MII spindle and abnormally dispersed chromosomes. $(\mathrm{H})$ is an example of an MIl spindle for which the morphology could not be analysed because of its orientation; spindle quality was classified as unidentifiable. PB, polar body. 
Table 3 Effect of vitrification and warming on the ability of microinjected LY to diffuse, during a 10 min post-injection incubation, from an immature oocyte into the surrounding cumulus cells via the gap junctions.

\begin{tabular}{lcccc}
\hline & & \multicolumn{2}{c}{ Extent of gap junction function } \\
\cline { 3 - 5 } Groups & $\begin{array}{c}\text { Number } \\
\text { of COCs }\end{array}$ & $\begin{array}{c}\text { Fully } \\
\text { open }(\%)\end{array}$ & $\begin{array}{c}\text { Partially } \\
\text { open }(\%)\end{array}$ & $\begin{array}{c}\text { Closed } \\
(\%)\end{array}$ \\
\hline Vitrified-warmed & 36 & $18(50)$ & $8(22.2)$ & $10(27.8)$ \\
CPA-exposed & 21 & $10(47.6)$ & $6(28.6)$ & $5(23.8)$ \\
Non-treated control & 32 & $17(53.1)$ & $8(25)$ & $7(21.9)$ \\
\hline
\end{tabular}

There was no effect of either vitrification or CPA exposure on gapjunction function in immature COCs.

our study, the cumulus cells may have prevented overexposure to CPA, whereas in Bogliolo et al.'s study, they may have precluded adequate exposure. Although they reached MII, the denuded vitrified ovine oocytes in Bogliolo et al.'s (2007) study showed a depletion of MAPK and MPF that would probably have compromised their developmental competence; this emphasises that meiotic competence is not a guarantee of developmental competence.

For mature (MII) oocytes, survival rates after cryopreservation by controlled rate freezing have been reported to be similar (Fabbri et al. 2001) or higher (Imoedemhe \& Sigue 1992) when human oocytes are cryopreserved within their cumulus investment than when they are denuded. However, other studies have reported better human MII oocyte survival if the cumulus was removed prior to freezing (Gook et al. 1993) and, since prior cumulus removal allows better evaluation of oocyte quality (Fabbri 2006) and any detrimental effects of removing the cumulus on subsequent zona penetrability are circumvented by using intracytoplasmic sperm injection rather than conventional IVF to achieve fertilisation, cumulus removal prior to cryopreservation is now a standard practice during cryopreservation of MII human oocytes. Moreover, recent clinical studies have produced very promising results in terms of percentages of injected oocytes developing to the blastocyst stage or resulting in ongoing pregnancies (Cobo et al. 2008, Cao et al. 2009). Nevertheless, the potential protective role of the cumulus during the vitrification of MII oocytes remains controversial, not least because some studies still record better results for cumulus-enclosed than denuded human vitrified oocytes (e.g. Kuwayama et al. 2005); there may also be between-species differences since there are reports of reduced oocyte viability and developmental competence in cattle oocytes vitrified with an intact cumulus (Chian et al. 2004), no effect of cumulus presence during vitrification of sheep oocytes (Zhang et al. 2009) and either a protective effect of the cumulus (Varga et al. 2006) or an effect of cumulus presence on the optimal time for exposing MII oocytes to CPA in pigs (Fujihira et al. 2005). Since there are considerable apparent between-species and study differences, it was appropriate to examine the effect of vitrifying MII equine oocytes with or without their cumulus investment on post-warming meiotic spindle quality. And while post-warming spindle quality was generally poor in vitrified-warmed oocytes, despite a $6 \mathrm{~h}$ post-warming incubation to allow spindle reassembly and repair (Rienzi et al. 2004), cumulus-enclosed oocytes fared significantly better than denuded oocytes (38 vs 3\% normal spindles). In short, our results support the hypothesis that the cumulus helps to protect equine oocytes from damage during vitrification. Although we are unable to elaborate on the precise nature of these damaging effects, it is possible that the apparent need for a protective cumulus barrier during vitrification of equine MII oocytes could relate to the relatively high concentrations of CPAs used (20\% ethylene glycol (EG), $20 \%$ DMSO, $0.5 \mathrm{M}$ sucrose) compared with current protocols for vitrifying human oocytes (e.g. 15\% EG, 15\% DMSO, 0.5 M sucrose: Cobo et al. 2008) and that it might be negated by reducing the concentrations of, or time of exposure to, the CPAs as reported for porcine oocytes (Fujihira et al. 2005) or by altering the temperature at which CPA exposure takes place. On the other hand, damage to the MII oocytes in the current study appeared to be induced primarily by vitrification and warming per se rather than CPA toxicity since exposing denuded oocytes to CPA without vitrification did not affect meiotic spindle quality.

In summary, the current study demonstrated that vitrifying immature equine COCs leads to the death of a modest proportion of peripheral cumulus cells. However, the death of these cells does not affect the ability of the oocyte to reach MII during subsequent IVM

Table 4 Meiotic spindle quality and chromatin dispersal in oocytes denuded at the GV stage and matured in vitro for $30 \mathrm{~h}$ either immediately or following vitrification-warming or exposure to cryoprotectants.

\begin{tabular}{|c|c|c|c|c|c|c|}
\hline \multirow[b]{2}{*}{ Group } & \multirow[b]{2}{*}{ No. of MII (\%) } & \multirow[b]{2}{*}{$\begin{array}{c}\text { Unidentifiable } \\
\text { morphology }(n)\end{array}$} & \multicolumn{2}{|c|}{ Spindle quality (\%) } & \multicolumn{2}{|c|}{ Chromatin dispersal (\%) } \\
\hline & & & $\begin{array}{l}\text { Normal/minor } \\
\text { damage }\end{array}$ & Severe damage/loss & None/minor & Severe \\
\hline Intact control (20) & $11(55)^{\mathrm{a}}$ & 2 & $8(88.9)^{\mathrm{a}}$ & $1(11.1)^{\mathrm{a}}$ & $8(88.9)^{\mathrm{a}}$ & $1(11.1)^{\mathrm{a}}$ \\
\hline Denuded (21) & $11(52.4)^{\mathrm{a}}$ & 0 & $8(72.7)^{\mathrm{a}}$ & $3(27.3)^{a}$ & $8(72.7)^{a}$ & $3(27.3)^{a}$ \\
\hline Denuded-CPA (20) & $10(50 \%)^{\mathrm{a}}$ & 0 & $4(40)^{b}$ & $6(60)^{b}$ & $5(50)^{b}$ & $5(50)^{b}$ \\
\hline Denuded-vitrified & $11(22.4)^{b}$ & 0 & $2(18.2)^{b}$ & $9(81.8)^{b}$ & $2(18.2)^{b}$ & $9(81.8)^{b}$ \\
\hline
\end{tabular}

$\mathrm{a}, \mathrm{b}, \mathrm{c}$ Within a column, different superscripts denote values that differ significantly. 
Table 5 Meiotic spindle quality and chromatin dispersal in MIl oocytes vitrified and warmed in the presence (cumulus-intact) or absence (denuded) of the cumulus complex.

\begin{tabular}{|c|c|c|c|c|c|c|}
\hline \multirow[b]{2}{*}{ Group } & \multirow[b]{2}{*}{$\begin{array}{l}\text { No. of } \\
\text { MIl oocytes }\end{array}$} & \multirow[b]{2}{*}{$\begin{array}{l}\text { Unidentifiable } \\
\text { morphology }(n)\end{array}$} & \multicolumn{2}{|c|}{ Spindle quality (\%) } & \multicolumn{2}{|c|}{ Chromatin dispersal (\%) } \\
\hline & & & $\begin{array}{l}\text { Normal/minor } \\
\text { damage }\end{array}$ & Severe damage/loss & None/minor & Severe \\
\hline Non-frozen control & 38 & 2 & $34(94.4)^{\mathrm{a}}$ & $2(5.6)^{\mathrm{a}}$ & $34(94.4)^{\mathrm{a}}$ & $2(5.6)^{\mathrm{a}}$ \\
\hline Cumulus intact-CPA & 25 & 0 & $23(92)^{a}$ & $2(8)^{\mathrm{a}}$ & $22(88)^{\mathrm{a}}$ & $3(12)^{\mathrm{a}}$ \\
\hline Cumulus intact-vitrified & 63 & 3 & $23(38.3)^{\mathrm{b}}$ & $37(61.7)^{\mathrm{b}}$ & $25(41.7)^{b}$ & $35(58.3)^{\mathrm{b}}$ \\
\hline Denuded-CPA & 30 & 3 & $24(88.9)^{\mathrm{a}}$ & $3(11.1)^{\mathrm{a}}$ & $25(92.6)^{\mathrm{a}}$ & $2(7.4)^{\mathrm{a}}$ \\
\hline Denuded-vitrified & 70 & 5 & $2(3.1)^{\mathrm{c}}$ & $63(96.9)^{\mathrm{c}}$ & $5(7.7)^{\mathrm{c}}$ & $60(92.3)^{c}$ \\
\hline
\end{tabular}

$\mathrm{a}, \mathrm{b}, \mathrm{c}$ Within a column, different superscripts denote values that differ significantly. Oocytes were incubated for $6 \mathrm{~h}$ post-warming to allow spindle reassembly.

presumably, at least in part, because of the location of the dead cells; the cumulus cells closer to the oocyte, and which are more likely to play an active role in communication, remained viable, structurally intact and maintained normal gap junction communication with the oocyte despite vitrification. The alternative explanation is that cumulus cells are, in any case, not required for nuclear maturation, as suggested by the comparable rates of nuclear maturation and MII spindle normality in oocytes matured with or without a cumulus. On the other hand, because vitrification or exposure of denuded GV oocytes to CPA did compromise their ability to reach MII with a normal spindle, it must be concluded that the presence of the cumulus during vitrification has protective effects independent of any subsequent active role during nuclear maturation. Similarly, since meiotic spindle quality was better preserved in MII oocytes vitrified within an intact cumulus than in denuded oocytes, it is concluded that cumulus cells protect MII equine oocytes against disruption of cytoplasmic factors important to meiotic spindle reassembly.

\section{Materials and Methods \\ Collection and culture of COCs}

COCs were collected and matured in vitro as described previously (Tharasanit et al. 2006a). In short, ovaries collected immediately after the slaughter of mares at an abattoir were transported to the laboratory at $30^{\circ} \mathrm{C}$. Following arrival at the laboratory within 3-4 h, COCs were harvested by aspirating the contents of follicles with a diameter of 5-30 mm using a 16-gauge needle connected via an infusion set to a vacuum pump. To increase the likelihood of oocyte recovery, the follicle lumen was then flushed 2-3 times with $0.9 \%$ saline supplemented with $25 \mathrm{IU} / \mathrm{ml}$ heparin (Leo Pharmaceuticals, Weesp, The Netherlands) and $0.1 \%$ (w/v) BSA (Sigma Chemical Co.) and, throughout aspiration and flushing, the follicle wall was scraped using the bevel of the needle.

Oocytes with a complete, compact, multilayered cumulus investment (Hinrichs et al. 1993) were selected using a dissecting stereomicroscope and maintained in HEPES buffered M199 supplemented with $0.014 \%$ (w/v) BSA; holding medium (HM). Groups of 25-30 COCs were then matured by incubation for $30 \mathrm{~h}$ in $500 \mu \mathrm{l}$ M199 supplemented with $10 \%(\mathrm{v} / \mathrm{v})$ heat-inactivated FCS (Gibco BRL), 0.01 units $/ \mathrm{ml}$ porcine $\mathrm{FSH}$ and 0.01 units $/ \mathrm{ml}$ equine $\mathrm{LH}$ (both from Sigma Chemical Co.) at $38.7^{\circ} \mathrm{C}$ in a humidified atmosphere of $5 \% \mathrm{CO}_{2}$-in-air.

\section{Vitrification and warming of oocytes}

Oocytes were vitrified using a modification of the OPS technique described by Vajta et al. (1998). OPS straws were made by heating $0.25 \mathrm{ml}$ polyvinyl chloride straws (IMV technologies; L'Aigle, France) over a $100{ }^{\circ} \mathrm{C}$ hot plate and stretching them until their outer diameter was halved. In preparation for vitrification, groups of 10 COCs were equilibrated for $30 \mathrm{~s}$ in a $100 \mu \mathrm{l}$ droplet of a pre-vitrification medium consisting of $10 \%(\mathrm{v} / \mathrm{v}) \mathrm{EG}$ and $10 \%(\mathrm{v} / \mathrm{v})$ DMSO (both Sigma Chemical Co.) in HM. Next, the COCs were incubated for $20-25 \mathrm{~s}$ in a $100 \mu \mathrm{l}$ droplet of vitrification solution; HM containing 20\% EG, 20\% DMSO and $0.5 \mathrm{M}$ sucrose (Sigma Chemical Co.). Finally, the oocytes were transferred to a $2 \mu \mathrm{l}$ droplet of fresh vitrification solution, loaded into an OPS straw by capillary action and, within 20-25 s, plunged into liquid nitrogen; all of the pre-vitrification stages were carried out at room temperature. After storage in liquid nitrogen for at least a week the straws were warmed by submerging them in $37^{\circ} \mathrm{C}$ HM containing $0.3 \mathrm{M}$ sucrose. The oocytes were then expelled into the warming medium and incubated for 5 min before washing and transfer to $\mathrm{HM}$ for further examination. To control for possible toxic effects of the vitrification and warming media, additional oocytes were exposed to both solutions for the normal durations, without intervening vitrification.

\section{Experiment 1: Effect of vitrifying immature COCs on cumulus cell viability}

The effect of vitrification on cumulus cell viability was investigated using 94 vitrified-warmed, 41 CPA exposed but not vitrified and 56 untreated COCs. After treatment, dead cumulus cells were labelled by incubating COCs in a $2 \mu \mathrm{M}$ solution of the cell membrane impermeant DNA marker, Ethd-1 (Molecular Probes Europe BV, Leiden, The Netherlands), in $\mathrm{HM}$ for $10 \mathrm{~min}$ at $37^{\circ} \mathrm{C}$. The COCs were then fixed overnight in $4 \%(\mathrm{w} / \mathrm{v})$ paraformaldehyde in PBS. Approximately, half of the fixed COCs were then washed in HM and labelled with 4'6-diamidino-2-phenylindole dihydrochloride (DAPI, 
Molecular Probes) to counter-stain the nuclei of previously live cells and allow dead and live cumulus cells to be differentiated and counted using an epifluorescence microscope (BH2-RFCA; Olympus, Tokyo, Japan) equipped with an eyepiece counting grid and $350 \mathrm{~nm}$ and $568 \mathrm{~nm}$ filters for DAPI and Ethd-1 respectively. The other half of the fixed COCs was stained by incubating for $30 \mathrm{~min}$ in $0.165 \mu \mathrm{M}$ Alexa Fluor 488 phalloidin (Molecular Probes) in PBS to label the actin

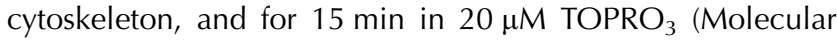
Probes) to visualise the nuclei of cumulus cells that were live until fixation. These COCs were then mounted on glass microscope slides and the distribution of dead cumulus cells was examined using a CLSM.

\section{Experiment 2: The relationship between cumulus viability and meiotic competence in vitrified COCs}

To examine the effect of dead cumulus cells on the ability of vitrified-thawed immature COCs to resume and complete meiosis, 248 COCs were allocated randomly to one of three treatments: 1$)$ non-frozen controls $(n=80), 2)$ CPA-exposed but not vitrified $(n=60)$ and 3$)$ vitrified-warmed $(n=108)$. As described in experiment 1 , dead cumulus cells were labelled with Ethd-1, but rather than being fixed, COCs were then examined at $37^{\circ} \mathrm{C}$ with an inverted epifluorescence microscope (IMT2, Olympus) equipped with a heated stage (Linkam Scientific Instrument, Tadworth, UK) and a $568 \mathrm{~nm}$ filter. The COCs were exposed to fluorescent light for a maximum of $30 \mathrm{~s}$ and ascribed a quality grade $(+1,+2$ or +3$)$ depending on the approximate area of Ethd- 1 staining (i.e. approximate proportion of dead cells: Fig. 1E-J).

Groups of 15-20 COCs from each cumulus quality class were matured in vitro for $30 \mathrm{~h}$. After IVM, to allow determination of maturation stage, oocytes were denuded of their cumulus cells by vortexing in calcium and magnesium free Earle's balanced salt solution (Gibco BRL) containing $0.1 \%$ $(\mathrm{w} / \mathrm{v})$ hyaluronidase and $0.25 \%(\mathrm{v} / \mathrm{v})$ trypsin-EDTA (both Sigma Chemical Co.). Next, they were incubated for $45 \mathrm{~min}$ at $37^{\circ} \mathrm{C}$ in a glycerol-based microtubule stabilising solution (Simerly \& Schatten 1993) before being fixed in 4\% paraformaldehyde. The oocytes were then incubated for $1 \mathrm{~h}$ at room temperature in a 1:100 solution of a monoclonal anti- $\alpha$-tubulin antibody (clone B1-5-1-2: Sigma Chemical Co.) in PBS supplemented with $0.1 \%$ BSA (PBS-BSA). After a further wash in PBS-BSA, the oocytes were incubated for $1 \mathrm{~h}$ in a 1:100 solution of a goat anti-mouse second antibody conjugated to tetramethylrhodamine isothiocyanate (TRITC; Sigma Chemical Co.) in PBS containing $2 \%(\mathrm{v} / \mathrm{v})$ goat serum. Finally, the oocytes were labelled with Alexa Fluor 488 phalloidin and $\mathrm{TOPRO}_{3}$ to label the actin microfilaments and chromatin in preparation for CLSM, as described in Experiment 1.

\section{Experiment 3: Effect of vitrification on COC connexin-43 expression and gap junction function}

The presence and location of gap junctions within immature COCs, and the effect of vitrification thereon, was examined by immunocytochemical staining for the gap junction specific protein, connexin 43. A total of 30 vitrified-warmed and 20 non-frozen control COCs were fixed overnight in 4\% paraformaldehyde before being washed twice in PBS-BSA and incubated for $2 \mathrm{~h}$ with a 1:100 solution of a mouse MAB against connexin-43 (Sigma Chemical Co.) in PBS supplemented with $0.1 \%$ Triton X-100 and $0.1 \%$ BSA. The COCs were then washed twice in PBS-BSA and incubated for $1 \mathrm{~h}$ in a 1:100 solution of a goat anti-mouse second antibody conjugated to TRITC (Sigma Chemical Co.). The COCs were additionally stained with Alexa Fluor 488 phalloidin and DAPI to label the actin microfilaments and nuclei of the cumulus cells. Finally, the labelled COCs were mounted on glass microscope slides and examined using a multiphoton laserscanning microscope.

Gap-junction function was investigated by studying the diffusion of LY from oocyte to cumulus complex in 36 vitrifiedwarmed, 21 CPA-exposed (not vitrified) and 32 untreated immature COCs, using the technique described by Colleoni et al. (2004). In short, COCs maintained at $37^{\circ} \mathrm{C}$ in a $5 \mu$ droplet of HEPES buffered synthetic oviductal fluid (Lazzari et al. 2002) under mineral oil were microinjected with a $3 \%$ solution of $L Y$ in $5 \mathrm{mM}$ lithium chloride (both Sigma Chemical Co.) using a 1-2 $\mu \mathrm{m}$ diameter injection needle produced using a glass micropipette puller (model P-87, Sutter instrument, CA, USA) and driven by a micromanipulator (Narishige Co. Ltd, Tokyo, Japan) mounted on an inverted microscope (Nikon Diaphot, Kawasaki, Japan). Gap junction function was assessed after a 10 min post-injection incubation by examining the passage of LY from the ooplasm into the cumulus-corona radiata complex. Gap junctions were classified as 'open' if at least $80 \%$ of the corona radiata cells exhibited fluorescence, 'partially open' if a smaller proportion of cells were stained with LY, or 'closed' if the LY was confined to the ooplasm (Fig. 2C-E).

\section{Experiment 4: Effect of cumulus removal on meiotic competence and cryopreservability of $G V$ oocytes}

To examine whether the cumulus is necessary for successful maturation of equine oocytes in vitro and/or plays an important role in protecting the oocyte during vitrification, freshly harvested COCs were mechanically denuded of their cumulus by repeated aspiration into a glass pipette and either matured in vitro for $30 \mathrm{~h}$ directly $(n=21)$, or vitrified and warmed prior to maturation $(n=49)$. Further controls included cumulus intact COCs $(n=20)$ matured in vitro and cumulus-denuded oocytes exposed to the vitrification and warming solutions, but not vitrified, prior to IVM $(n=20)$. After maturation, the oocytes were fixed and stained as described in experiment 2 with a monoclonal anti- $\alpha$-tubulin antibody, Alexa Fluor 488 phalloidin and $\mathrm{TOPRO}_{3}$ for subsequent examination of meiotic spindle quality by CLSM.

\section{Experiment 5: Effect of cumulus removal on the ability of in vitro matured equine oocytes to withstand vitrification}

To examine whether removing cumulus cells would affect the ability of MII oocytes to withstand vitrification in terms of subsequent meiotic spindle quality, COCs were matured in vitro for $30 \mathrm{~h}$ and either denuded of their cumulus investment 
Table 6 Classification of meiotic spindle quality and chromatin configuration in metaphase II (MII) stage equine oocytes (adapted from Saunders \& Parks 1999).

\begin{tabular}{|c|c|c|c|}
\hline Cell structure & Normal/minor changes & Abnormal & Absent \\
\hline Meiotic spindle & $\begin{array}{l}\text { Symmetrical, barrel-shaped spindle } \\
\text { with two anastral poles }\end{array}$ & $\begin{array}{l}\text { Disorganised, clumped or dispersed } \\
\text { spindle elements, or multiple } \\
\text { spindle-like structures }\end{array}$ & $\begin{array}{l}\text { No visible spindle, despite two sets of } \\
\text { chromatin being present (MII plate) }\end{array}$ \\
\hline Chromatin & $\begin{array}{l}\text { Two sets of chromatin aligned at the } \\
\text { centre of the barrel-shaped spindle }\end{array}$ & $\begin{array}{l}\text { Aberrations of chromatin arrangement; } \\
\text { clumping, or dispersal from the } \\
\text { centre of the spindle }\end{array}$ & Not applicable \\
\hline
\end{tabular}

$(n=120)$ or left with an intact cumulus $(n=115)$ before being vitrified. A further 50 cumulus-intact and 49 cumulus-denuded in vitro matured oocytes were exposed to CPA without vitrification, and 61 COCs were used as non-treated controls. After warming or CPA exposure, oocytes were incubated for a further $6 \mathrm{~h}$ to allow spontaneous repair of any spindle damage; they were then fixed and stained with a monoclonal anti- $\alpha$ tubulin antibody, Alexa Fluor 488 phalloidin and $\mathrm{TOPRO}_{3}$ to allow examination of meiotic spindle quality by CLSM.

\section{Confocal and multiphoton laser scanning microscopy}

Labelled oocytes or COCs were mounted in a $2 \mu$ droplet of antifade medium (to retard photobleaching; Vectashield, Vector Labs, Burlingame, CA, USA) and sealed under a coverslip using nail polish. Localisation of dead cumulus cells within a COC or examination of an oocyte's cytoskeleton (actin microfilaments and microtubules) was performed using a CLSM mounted on an inverted microscope (Leica DM IRBE, Heidelberg, Germany). A combination of a 488-Argon-ion, a $568 \mathrm{~nm}$ Krypton and a 633 Helium Neon laser was used to produce sequential optical scans of the Alexa Fluor 488 Phalloidin, TRITC/Ethd-1 and $\mathrm{TOPRO}_{3}$ stained structures respectively.

The expression of connexin-43 in COCs was examined using a Bio-rad Radiance 2100MP confocal and multiphoton system (BioRad) mounted on a Nikon TE300 inverted microscope (Uvikon, Bunnik, The Netherlands); a combination of a 488Argon-ion and a 543-Helium Neon laser was used to produce sequential optical scans of the Alexa Fluor 488-Phalloidin and TRITC respectively, while DAPI-stained nuclear material was excited using a $100 \mathrm{fs}$ pulsed $780 \mathrm{~nm}$ excitation laser source (a mode-locked Titanium: Saphire laser: Tsunami, Spectra Physics, Mountain View, CA, USA). The images produced by sequential scans with the different colour channels were merged and recorded digitally using Leica confocal software (version 2.61: Leica Microsystems, Heidelberg, Germany).

Micrographs produced by CLSM or multiphoton microscopy were subsequently examined using Adobe Photoshop 7 (Adobe System Inc.). During cytoskeleton assessment, oocytes were assigned a score depending on the quality of the meiotic spindle and chromatin, as outlined in Table 6. Briefly, the actin microfilament distribution was classified as normal if the staining was distributed evenly throughout the tranzonal channels and ooplasm, except for a slight intensification just beneath the oolemma. The meiotic spindle was classified as normal if it assumed a symmetrical barrel-shape with two anastral poles and two equal sets of chromosomes aligned at its centre (Fig. 2F), as described by Tremoleda et al. (2001). Any changes in the distribution of actin or the morphology of the meiotic spindle were classified by their apparent severity (minor or severe); abnormalities included clumping of the actin microfilaments and disorganisation or dispersal of the meiotic spindle and/or chromatin (Fig. 2G). In some cases, oocytes lacked any visible microtubular structures around the MII chromosomes and were therefore recorded to have lost their meiotic spindle. On other occasions, the meiotic spindle was aligned such that it was impossible to evaluate its normality; these spindles were classified as having an unidentifiable morphology (Fig. 2H).

\section{Statistical analysis}

Statistical analysis was performed using SPSS 12.0.1 for Windows (SPSS Inc., Chicago, IL, USA) and logistic regression analysis (MaCullagh \& Nelder 1989). Differences between experimental groups in maturation rate, percentages of dead cumulus cells, meiotic spindle quality, chromatin configuration and diffusion of LY were compared using the model: In $\pi /(1-\pi)=\alpha+$ treatment (where $\pi$, frequency of positive outcome, and $\alpha$, the intercept). The number of cumulus cells per COC (exp. 1) was compared using one-way ANOVA. In all cases, differences were considered significant if $P<0.05$.

\section{Declaration of interest}

The authors confirm that there is no conflict of interest that could be perceived as prejudicing the impartiality of the research reported.

\section{Funding}

T Tharasanit was supported by a Utrecht-Thailand Scholarship Programme and by Intervet Nederland B.V, Boxmeer, The Netherlands.

\section{Acknowledgements}

The authors would like to thank staff and students at the cell biological laboratory of the Department of Farm Animal Health, Utrecht University for assisting in the recovery of horse COCs and, in particular, Dr Bernard Roelen for constructively criticising this manuscript. The confocal and multiphoton laser scanning microscopic examination of oocytes was performed at the Centre for Cell Imaging of Utrecht University's Department of Biochemistry and Cell Biology. 


\section{References}

Agca Y, Liu J, Peter AT, Critser ES \& Critser JK 1998 Effect of developmental stage on bovine oocyte plasma membrane water and cryoprotectant permeability characteristics. Molecular Reproduction and Development 49 408-415.

Ashwood-Smith MJ, Morris GW, Fowler R, Appleton TC \& Ashorn R 1988 Physical factors are involved in the destruction of embryos and oocytes during freezing and thawing procedures. Human Reproduction 3 795-802.

Atabay EC, Takahashi Y, Katagiri S, Nagano M, Koga A \& Kanai Y 2004 Vitrification of bovine oocytes and its application to intergeneric somatic cell nucleus transfer. Theriogenology 61 15-23.

Bogliolo L, Ariu F, Fois S, Rosati I, Zedda MT, Leoni G, Succu S, Pau S \& Ledda S 2007 Morphological and biochemical analysis of immature ovine oocytes vitrified with or without cumulus cells. Theriogenology 68 $1138-1149$.

Cao YX, Xing Q, Li L, Cong L, Zhang ZG, Wei ZL \& Zhou P 2009 Comparison of survival and embryonic development in human oocytes cryopreserved by slow-freezing and vitrification. Fertility and Sterility [in press] DOI: 10.1016/j.fertnstert.2008.08.069.

Chen C 1986 Pregnancy after human oocyte cryopreservation. Lancet 1 884-886.

Chian RC, Kuwayama M, Tan L, Tan J, Kato O \& Nagai T 2004 High survival rate of bovine oocytes matured in vitro following vitrification. Journal of Reproduction and Development 50 685-696.

Chian RC, Huang JYJ, Gilbert L, Son WY, Holzer H, Cui SJ, Buckett WM, Tulandi T \& Tan SL 2009 Obstetric outcomes following vitrification of in vitro and in vivo matured oocytes. Fertility and Sterility [in press] DOI: 10.1016/j.fertnstert.2008.04.014.

Cobo A, Kuwayama M, Pérez S, Ruiz A, Pellicer A \& Remohí J 2008 Comparison of concomitant outcome achieved with fresh and cryopreserved donor oocytes vitrified by the Cryotop method. Fertility and Sterility 89 1657-1664.

Colleoni S, Luciano AM \& Gandolfi F 2004 Cumulus-oocyte communications in the horse: role of the breeding season and of the maturation medium. Reproduction in Domestic Animals 39 70-75.

Coticchio G, Bonu MA, Sciajno R, Sereni E, Bianchi V \& Borini A 2007 Truths and myths of oocyte sensitivity to controlled rate freezing. Reproductive Biomedicine Online 15 24-30.

Dinnyes A, Dai Y, Jiang S \& Yang X 2000 High developmental rates of vitrified bovine oocytes following parthenogenetic activation, in vitro fertilization, and somatic cell nuclear transfer. Biology of Reproduction $63513-518$.

Fabbri R 2006 Cryopreservation of human oocytes and ovarian tissue. Cell and Tissue Banking 7 113-122.

Fabbri R, Porcu E, Marsella T, Rocchetta G, Venturoli S \& Flamigni C 2001 Human oocyte cryopreservation: new perspectives regarding oocyte survival. Human Reproduction 16 411-416.

Fan HY \& Sun QY 2004 Involvement of mitogen-activated protein kinase cascade during oocyte maturation and fertilization in mammals. Biology of Reproduction 70 535-547.

Fujihira T, Nagai H \& Fukui Y 2005 Relationship between equilibration times and the presence of cumulus cells, and effect of Taxol treatment for vitrification of in vitro matured porcine oocytes. Cryobiology $\mathbf{5 1}$ 339-343.

Fuku E, Kojima T, Shioya Y, Marcus GJ \& Downey BR 1992 In vitro fertilization and development of frozen-thawed bovine oocytes. Cryobiology 29 485-492.

Ge L, Han D, Lan GC, Zhou P, Liu Y, Zhang X, Sui HS \& Tan JH 2008 Factors affecting the in vitro action of cumulus cells on the maturing mouse oocytes. Molecular Reproduction and Development 75 136-142.

Ghetler Y, Skutelsky E, Ben Nun I, Ben Dor L, Amihai D \& Shalgi R 2006 Human oocyte cryopreservation and the fate of cortical granules. Fertility and Sterility $86210-216$.

Gilula NB, Reeves OR \& Steinbach A 1972 Metabolic coupling, ionic coupling and cell contacts. Nature 235 262-265.

Godard NM, Pukazhenthi BS, Wildt DE \& Comizzoli P 2009 Paracrine factors from cumulus-enclosed oocytes ensure the successful maturation and fertilization in vitro of denuded oocytes in the cat model. Fertility and Sterility [in press] DOI: 10.1016/j.fertnstert.2008.05.069.
Gook DA \& Edgar DH 2007 Human oocyte cryopreservation. Human Reproduction Update 13 591-605.

Gook DA, Osborn SM \& Johnston WI 1993 Cryopreservation of mouse and human oocytes using 1,2-propanediol and the configuration of the meiotic spindle. Human Reproduction 8 1101-1109.

Hassan HA 2001 Cumulus cell contribution to cytoplasmic maturation and oocyte developmental competence in vitro. Journal of Assisted Reproduction and Genetics 18 539-543.

Hinrichs K 1998 Production of embryos by assisted reproduction in the horse. Theriogenology 49 13-21.

Hinrichs K, Schmidt AL, Friedman PP, Selgrath JP \& Martin MG In vitro maturation of horse oocytes: characterization of chromatin configuration using fluorescence microscopy. Biology of Reproduction 48 363-370.

Hochi S, Fujimoto T, Choi YH, Braun J \& Oguri N 1994 Cryopreservation of equine oocytes by 2-step freezing. Theriogenology 42 1085-1094.

Hochi S, Kozawa M, Fujimoto T, Hondo E, Yamada J \& Oguri N 1996 In vitro maturation and transmission electron microscopic observation of horse oocytes after vitrification. Cryobiology 33 300-310.

Hurtt AE, Landim-Alvarenga F, Seidel GE Jr \& Squires EL 2000 Vitrification of immature and mature equine and bovine oocytes in an ethylene glycol, ficoll and sucrose solution using open-pulled straws. Theriogenology 54 119-128.

Hyttel P, Vajta G \& Callesen H 2000 Vitrification of bovine oocytes with the open pulled straw method: ultrastructural consequences. Molecular Reproduction and Development 56 80-88.

Imoedemhe DG \& Sigue AB 1992 Survival of human oocytes cryopreserved with or without the cumulus in 1,2-propanediol. Journal of Assisted Reproduction and Genetics 9 323-327.

Kubota C, Yang X, Dinnyes A, Todoroki J, Yamakuchi H, Mizoshita K, Inohae S \& Tabara N 1998 In vitro and in vivo survival of frozen-thawed bovine oocytes after IVF, nuclear transfer, and parthenogenetic activation. Molecular Reproduction and Development 51 281-286.

Kuwayama M, Vajta G, Kato O \& Leibo SP 2005 Highly efficient vitrification method for cryopreservation of human oocytes. Reproductive Biomedicine Online 11 300-308.

Lazzari G, Wrenzycki C, Herrmann D, Duchi R, Kruip T, Niemann H \& Galli C 2002 Cellular and molecular deviations in bovine in vitroproduced embryos are related to the large offspring syndrome. Biology of Reproduction 67 767-775.

Leibo SP 1980 Water permeability and its activation energy of fertilized and unfertilized mouse ova. Journal of Membrane Biology 53 179-188.

Lu Q, Dunn RL, Angeles R \& Smith GD 2002 Regulation of spindle formation by active mitogen-activated protein kinase and protein phosphatase 2A during mouse oocyte meiosis. Biology of Reproduction 66 29-37.

Maclellan LJ, Carnevale EM, Coutinho da Silva MA, Scoggin CF, Bruemmer JE \& Squires EL 2002 Pregnancies from vitrified equine oocytes collected from super-stimulated and non-stimulated mares. Theriogenology 58 911-919.

MaCullagh P \& Nelder JA 1989 In Binary Data, pp 98-135. Eds P MaCullagh \& JA Nelder. London: Chapman, \& Hall.

Marchal R, Caillaud M, Martoriati A, Gerard N, Mermillod P \& Goudet G 2003 Effect of growth hormone $(\mathrm{GH})$ on in vitro nuclear and cytoplasmic oocyte maturation, cumulus expansion, hyaluronan synthases, and connexins 32 and 43 expression, and GH receptor messenger RNA expression in equine and porcine species. Biology of Reproduction 69 1013-1022.

Mattioli M \& Barboni B 2000 Signal transduction mechanism for LH in the cumulus-oocyte complex. Molecular and Cellular Endocrinology 161 $19-23$.

Park SE, Son WY, Lee SH, Lee KA, Ko JJ \& Cha KY 1997 Chromosome and spindle configurations of human oocytes matured in vitro after cryopreservation at the germinal vesicle stage. Fertility and Sterility 68 920-926.

Parks JE \& Ruffing NA 1992 Factors affecting low temperature survival of mammalian oocytes. Theriogenology 37 59-73.

Rienzi L, Martinez F, Ubaldi F, Minasi MG, lacobelli M, Tesarik J \& Greco E 2004 Polscop analysis of meiotic spindle changes in living metaphase II human oocytes during the freezing and thawing procedures. Human Reproduction 19 655-659.

Ruppert-Lingham CJ, Paynter SJ, Godfrey J, Fuller BJ \& Shaw RW 2003 Developmental potential of murine germinal vesicle stage cumulus- 
oocyte complexes following exposure to dimethylsulphoxide or cryopreservation: loss of membrane integrity of cumulus cells after thawing. Human Reproduction 18 392-398.

Sathananthan AH, Ng SC, Trounson AO, Bongso A, Ratnam SS, Ho J, Mok H \& Lee MN 1988 The effects of ultrarapid freezing on meiotic and mitotic spindles of mouse oocytes and embryos. Gamete Research 21 385-401.

Saunders KM \& Parks JE 1999 Effects of cryopreservation procedures on the cytology and fertilization rate of in vitro-matured bovine oocytes. Biology of Reproduction 61 178-187.

Shimada M, Maeda T \& Terada T 2001 Dynamic changes of connexin-43, gap junctional protein, in uter layers of cumulus cells are regulated by PKC and PI 3-Kinase during meiotic resumption in porcine oocytes. Biology of Reproduction 64 1255-1263.

Simerly C \& Schatten H 1993 In Techniques for Localization of Specific Molecules in Oocytes and Embryos, pp 516-522. Eds PM Wassarman \& ML DePamphilis. New York: Academic Press.

Sutovsky P, Flechon J, Flechon B, Motlik J, Peynot N, Chesne P \& Heyman Y 1993 Dynamic changes of gap junctions and cytoskeleton during in vitro culture of cattle oocyte cumulus complexes. Biology of Reproduction 49 1277-1287.

Tanghe S, Van Soom A, Nauwynck H, Coryn M \& de Kruif A 2002 Minireview: functions of the cumulus oophorus during oocyte maturation, ovulation, and fertilization. Molecular Reproduction and Development 61 414-424.

Tanghe S, Van Soom A, Mehrzad J, Maes D, Duchateau L \& de Kruif A 2003 Cumulus contributions during bovine fertilization in vitro. Theriogenology $60135-149$.

Tharasanit T, Colenbrander B \& Stout TAE 2006a Effect of maturation stage at cryopreservation on post-thaw cytoskeleton quality and fertilizability of equine oocytes. Molecular Reproduction and Development 73 627-637.

Tharasanit T, Colleoni S, Lazzari G, Colenbrander B, Galli C \& Stout TAE $2006 b$ Effect of cumulus morphology and maturation stage on the cryopreservability of equine oocytes. Reproduction 132 759-769.
Tremoleda JL, Schoevers EJ, Stout TA, Colenbrander B \& Bevers MM 2001 Organisation of the cytoskeleton during in vitro maturation of horse oocytes. Molecular Reproduction and Development $\mathbf{6 0}$ 260-269.

Vajta G, Holm P, Kuwayama M, Booth PJ, Jacobsen H, Greve T \& Callesen H 1998 Open pulled straw (OPS) vitrification: a new way to reduce cryoinjuries of bovine ova and embryos. Molecular Reproduction and Development $\mathbf{5 1} 53-58$.

Vanderhyden BC \& Armstrong DT 1989 Role of cumulus cells and serum on the in vitro maturation, fertilization, and subsequent development of rat oocytes. Biology of Reproduction 40 720-728.

Varga E, Gardon JC \& Bali Papp A 2006 Effect of open pulled straw (OPS) vitrification on the fertilisation rate and developmental competence of porcine oocytes. Acta Veterinaria Hungarica 54 107-116.

Verlhac MH, Kubiak JZ, Clarke HJ \& Maro B 1994 Microtubule and chromatin behavior follow MAP kinase activity but not MPF activity during meiosis in mouse oocytes. Development 120 1017-1025.

Zhang L, Jiang S, Wozniak PJ, Yang X \& Godke RA 1995 Cumulus cell function during bovine oocyte maturation, fertilization, and embryo development in vitro. Molecular Reproduction and Development 40 338-344.

Zhang J, Nedambale TL, Yang M \& Li J 2009 Improved development of ovine matured oocyte following solid surface vitrification (SSV): effect of cumulus cells and cytoskeleton stabilizer. Animal Reproduction Science 110 46-55.

Received 5 August 2008

First decision 18 September 2008

Revised manuscript received 11 November 2008

Accepted 9 December 2008 